\title{
On 'Trade Induced Technical Change: The Impact of Chinese Imports on Innovation, IT and Productivity'
}

Citation for published version (APA):

Campbell, D. L., \& Mau, K. (2020). On 'Trade Induced Technical Change: The Impact of Chinese Imports on Innovation, IT and Productivity'. Maastricht University, Graduate School of Business and Economics. GSBE Research Memoranda No. 019 https://doi.org/10.26481/umagsb.2020019

Document status and date:

Published: 09/07/2020

DOI:

10.26481/umagsb.2020019

Document Version:

Publisher's PDF, also known as Version of record

\section{Please check the document version of this publication:}

- A submitted manuscript is the version of the article upon submission and before peer-review. There can be important differences between the submitted version and the official published version of record.

People interested in the research are advised to contact the author for the final version of the publication, or visit the DOI to the publisher's website.

- The final author version and the galley proof are versions of the publication after peer review.

- The final published version features the final layout of the paper including the volume, issue and page numbers.

Link to publication

\footnotetext{
General rights rights.

- You may freely distribute the URL identifying the publication in the public portal. please follow below link for the End User Agreement:

www.umlib.nl/taverne-license

Take down policy

If you believe that this document breaches copyright please contact us at:

repository@maastrichtuniversity.nl

providing details and we will investigate your claim.
}

Copyright and moral rights for the publications made accessible in the public portal are retained by the authors and/or other copyright owners and it is a condition of accessing publications that users recognise and abide by the legal requirements associated with these

- Users may download and print one copy of any publication from the public portal for the purpose of private study or research.

- You may not further distribute the material or use it for any profit-making activity or commercial gain

If the publication is distributed under the terms of Article $25 \mathrm{fa}$ of the Dutch Copyright Act, indicated by the "Taverne" license above, 
Douglas L. Campbell, Karsten Mau

On "Trade Induced Technical

Change: The Impact of Chinese Imports on Innovation, IT and Productivity"

RM/20/019

ISSN: $2666-8807$

\section{GSBE}

Maastricht University School of Business and Economics

Graduate School of Business and Economics

P.O Box 616

NL-6200 MD Maastricht

The Netherlands 


\title{
On "Trade Induced Technical Change: The Impact of Chinese Imports on Innovation, IT and Productivity" ${ }^{\prime \dagger}$
}

Douglas L. Campbell ${ }^{\S}$

New Economic School
Karsten Mau

Maastricht University

June, 2020

\begin{abstract}
Bloom, Draca, and Van Reenen (2016) find that Chinese import competition induced a rise in patenting, IT adoption, and TFP by up to $30 \%$ of the total increase in Europe in the late 1990s and early 2000s. We uncover several coding errors in an important robustness check of their patent results. When corrected, we find no statistically significant relationship between Chinese competition and patents. Other specifications in the original paper use a problematic $\log (1+$ patents $)$ transformation. This normalization induces bias given low average patent counts for firms in China-competing sectors, and rapidly declining patents across the sample.
\end{abstract}

JEL Classification: F14, F13, L25, L60

Keywords: Patents, China, Europe, Textiles, Trade Shocks, Manufacturing

$\dagger$. Special thanks are in order to Nicholas Bloom, Mirko Draca, and John Van Reenen for their pathbreaking study, for providing their data on their webpages, and for responding quickly and gracefully to questions about their data. We also thank participants at the CES Ifo Institute Mountain Retreat in Austria in 2018, the iCare7 conference in Perm, and the 25 Years of Transition Conference in Gdansk, Poland for their comments, and to Marta Troya Martinez for her helpful comments.

§. Corresponding author. E-mail: dcampbell@nes.ru, dolcampb@gmail.com. 


\section{Introduction}

The rise of Chinese import competition in advanced markets is one of the transformative events of the past 30 years of economic history. A major question is what impact this event has had on innovation. In an influential contribution, Bloom et al. (2016, hereafter BDvR) find that increased Chinese import competition in Europe in the late 1990s and early 2000s stimulated growth in patenting, IT, and TFP by up to $30 \%$. This is a remarkable result which contradicts Autor et al. (forthcoming), who find a negative impact of Chinese competition on US patents.

We find that BDvR make several coding errors in their Table 7 robustness check on patents, which uses a negative binomial regression. When corrected, we find that Chinese competition either reduced or had no significant impact on patenting in Europe.

BDvR's research design is an intuitive difference-in-difference strategy, comparing patents held by European firms in sectors that were more or less exposed to Chinese competition before and after China joined the WTO. Since there are many firms with zero patents, for most of their paper, BDvR normalize patents by adding one and then taking $\log$ differences $(e . g ., \Delta \log (1+$ patents $))$. This solution is generally problematic, and it is particularly so in this instance. The reason is that adding a small positive constant impacts smaller values more than larger ones, and firms in the China-competing sectors had relatively few patents to begin with. In addition, patents in all sectors converge toward zero in their data, creating upward bias in patent growth for firms with few initial patents.

The single exercise in BDvR immune from this critique is their robustness check using a negative binomial regression, designed to estimate count data models including frequent zero observations. No variable transformation is needed in that case. However, they make several coding errors on implementation, such as continuing to normalize

patents by adding one and including different FEs than what they described in the text of their paper. When we estimate the model using actual patent data without a transformation, there is no correlation between Chinese competition and patents. When we also include their intended FEs, we find a negative and significant relationship.

\section{The BDvR Patent Data}

We use BDvR's data. The firm-level variables for 12 European countries mostly come from Bureau Van Dijk's Amadeus, and are then matched to UN Comtrade trade data at 
the 4-digit SIC level using Pierce and Schott (2012)'s trade data concordance. ${ }^{1}$ Other sector-level variables come from Eurostat's Prodcom database.

\subsection{Difference-in-Difference Diagram}

In Figure 1, we present a standard difference-in-difference event study diagram for two of the main data samples used by BDvR (the baseline sample and a longer one). BDvR used the removal of textile quotas upon China's WTO entry as a proxy or IV for intensifying competition. We compare the evolution of patents in textile sectors in which the quotas on Chinese imports were most binding before their removal (and thus, the sectors in which Chinese imports increased the most following removal), to sectors in which the quotas did not bind (and thus the removal of quotas mattered less).

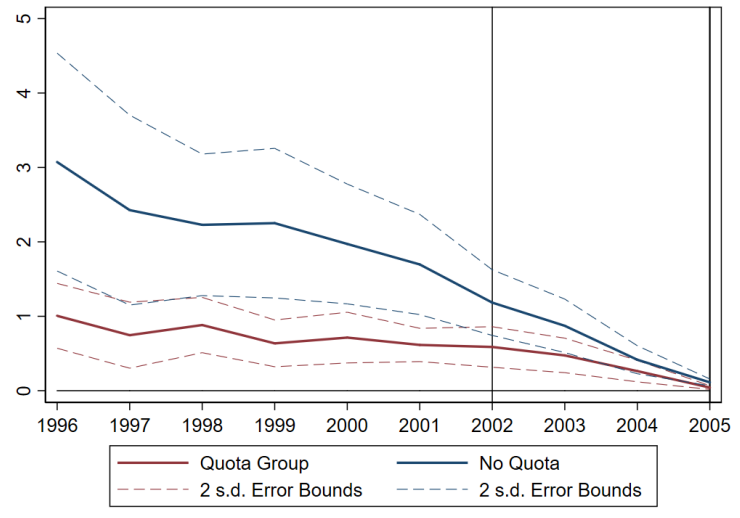

(a) Baseline Panel

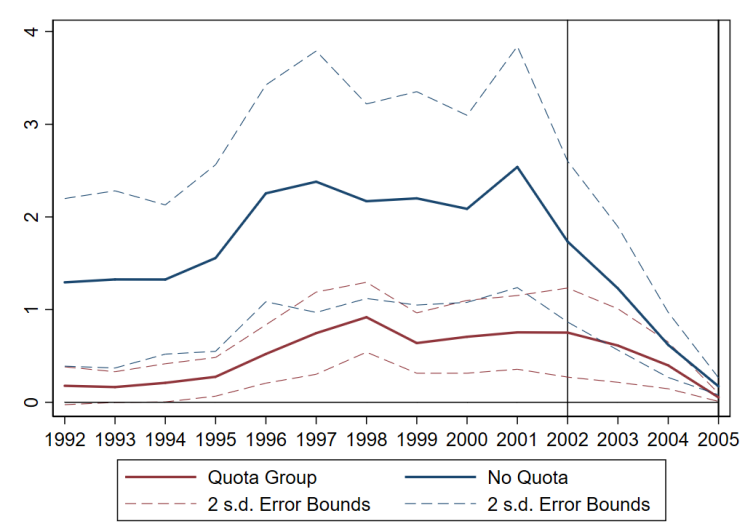

(b) Long Panel

Figure 1: Avg. Patents by Firm, Textile Sector: Sectors with Quota vs. Others

Notes: The red solid line shows the average patents over time in China-competing textile sectors (firms in sectors that faced textile quotas before they were relaxed and removed), with two standard deviation error bounds (the red dashed lines; computed by regressing patents per firm on a constant for each year). The blue lines show the evolution of average patents for textile firms in the "no quota" group. The first black vertical line denotes China's accession to the WTO, and the second one shows when the final quotas were removed.

In Panel (a), it can be seen that patents converge to zero for both the treatment and control group. This declining trend in patents arises because each patent is counted by the year of application, and in the later years, the patents may still have been pending at time of data collection. In addition, initial patents are lower for the China-competing

1. Their data is available here: http://www.stanford.edu/ nbloom/TITC.zip. The countries in the sample include Austria, Denmark, Finland, France, Germany, Ireland, Italy, Norway, Spain, Sweden, Switzerland, and the UK. 
group, implying a larger bias from adding one. There is also a difference in the pre-trends between the treatment and control groups.

BDvR use the long panel to show that their results are robust to controlling for sectoral and firm-level trends. However, the same tapering is present in Panel (b), where it can be seen that patents in the China-competing sectors (red line) also converge toward zero. From 2000 to 2005, the raw percentage decline in both the China-competing and non-competing groups is the same.

\subsection{Implications of Normalizing Patents}

If there are similar percentage declines in patents in the treatment and control groups, why do BDvR find a large and significant impact of Chinese competition? The reason is that their results are biased in part due to: $(1)$ the (patents +1 ) normalization, $(2)$ the differential levels of patents in the China-competing and non-competing sectors, and (3) the tapering of the patent data. The small absolute number of average patents per firm exacerbates the bias. To fix ideas, in Table 1, Panel A, we show that in the baseline sample average patents per firm fell by $94 \%$ for firms in sectors that compete with China the most from 2000 to 2005, but also fell by $94 \%$ for firms in sectors that were less exposed to China. However, if we first normalize patents by adding one and then compute the percentage change, we arrive at a $39 \%$ decline for the China-competing firms vs. a $63 \%$ decline for other firms. This difference is an artifact of the normalization

and the lower level of initial patents among China-competing firms. In Panel B, we see that the tapering induces bias in the longer sample as well.

\section{Negative Binomial Panel Regressions}

Given the concerns with the one plus patents normalization, BDvR's negative binomial regression becomes a critical robustness check. ${ }^{2}$ Following the empirical workhorse model in the patenting literature (Hausman et al., 1984), BDvR adopt a negative binomial panel regression specification of the following form:

$$
P A T_{i j k t}=\exp \left[\alpha I M P_{j k t}^{C H N}+x_{i k j 0}^{\prime} \beta+f_{k t}\right]+\nu_{i j k t}
$$

2. The problem of adding one has been shown to produce biased estimates in many other settings. For example, Silva and Tenreyro (2006) and Head and Mayer (2014) in the empirical trade literature, or Bellego and Pape (2019) for a more general discussion. Bellemare and Wichman (2020) recommend using a zero-inflated poisson or negative binomial when the dependent variable contains many zeros. 
Table 1: Implications of Normalizing Patents

\begin{tabular}{|c|c|c|c|c|}
\hline Sample & Measure & $\begin{array}{l}\text { Avg. Patents per } \\
\text { Firm, } 2000\end{array}$ & $\begin{array}{l}\text { Avg. Patents per } \\
\text { Firm, } 2005\end{array}$ & \% Change \\
\hline \multicolumn{5}{|l|}{ Panel A: Baseline Sample } \\
\hline \multirow[t]{2}{*}{ China-Competing Firms (Quotas Bind) } & Patents & 0.72 & 0.042 & $-94 \%$ \\
\hline & Patents +1 & 1.72 & 1.042 & $-39 \%$ \\
\hline \multirow[t]{2}{*}{ Other Firms (Quotas not Binding) } & Patents & 1.97 & 0.11 & $-94 \%$ \\
\hline & Patents +1 & 2.97 & 1.11 & $-63 \%$ \\
\hline \multicolumn{5}{|l|}{ Panel B: Long Sample } \\
\hline \multirow[t]{2}{*}{ China-Competing Firms (Quotas Bind) } & Patents & 0.71 & 0.053 & $-92 \%$ \\
\hline & Patents +1 & 1.71 & 1.053 & $-38 \%$ \\
\hline \multirow[t]{2}{*}{ Other Firms (Quotas not Binding) } & Patents & 2.09 & 0.17 & $-92 \%$ \\
\hline & Patents +1 & 3.09 & 1.17 & $-62 \%$ \\
\hline
\end{tabular}

Notes: We compare the $\%$ decline in patents between 2000 and 2005, the period in the sample when Chinese competition increases the most, using two different measures: average patents per firm, and average patents per firm plus one, the latter measure being the one used by BDvR. Panel A includes data for BDvR's short data set. Panel B uses data from BDvR's long data panel.

where $I M P_{j k t}^{C H N}$ is the share of imports from China in sector $j$ in country $k$ at time $t$, $x_{i k j 0}^{\prime}$ denotes a vector of two controls, initial pre-sample patents, and a dummy for zero patents (the latter two variables included to approximate firm FEs, according to BDvR), and $f_{k t}$ are country*year interactive fixed effects. BDvR then estimate this model over the period 1996 to 2005.

However, when they implement this regression, they make three coding errors: (1) they continue to use one plus patents as their dependent variable; (2) they replace the country*year interactive FEs with separate year and country dummies; and (3) they inadvertently include 4-digit SIC FEs, which are absent from previous regressions using patents. We correct these errors one by one.

In the first column of Table 2, we replicate BDvR's Table 7, column (3), estimating a negative binomial regression. This regression inadvertently uses patents plus one as the dependent variable and also contains different fixed effects than described in the text of their paper. In column (2) we run the same regression using the actual patent count (instead of patents plus one). When we do so, we get a negative, albeit insignificant, coefficient on Chinese imports. When we also include country*year FEs, the sign flips but remains statistically insignificant. In column (4), when we also exclude the 4-digit SIC FEs, we find a negative and significant correlation between Chinese imports and 
patents. Column (4) is the regression that BDvR intended to run. In conclusion, we find that the positive relationship between Chinese imports and patents is not robust.

Table 2: The Impact of Chinese Competition on Patent Growth

\begin{tabular}{lcccc}
\hline \hline & $\begin{array}{c}(1) \\
\text { Negative Binomial } \\
\text { BDV Baseline }\end{array}$ & $\begin{array}{c}(2) \\
\text { Negative Binomial } \\
\text { Change Dep. Var. }\end{array}$ & $\begin{array}{c}\text { Negative Binomial } \\
\text { +Cty*Year FEs }\end{array}$ & $\begin{array}{c}\text { Negative Binomial } \\
\text { ex-SIC4 FEs }\end{array}$ \\
\hline $\begin{array}{l}\text { Level of Chinese Imports } \\
\left(M_{j k}^{\text {China }} / M_{j k}^{\text {World }}\right)\end{array}$ & $0.40^{* *}$ & -0.15 & 0.12 & $-0.73^{* *}$ \\
& $(0.17)$ & $(0.47)$ & $(0.49)$ & $(0.34)$ \\
\hline Dependent Variable & 1+Patents & Patents & Patents & Patents \\
Country*Year FEs & No & No & Yes & Yes \\
SIC4 Sector FEs & Yes & Yes & Yes & No \\
Country FEs & Yes & Yes & No & No \\
Year FEs & Yes & Yes & 1,578 & 1,578 \\
Clusters & 1,578 & 1,578 & 8,780 & 8,780 \\
Firms & 8,780 & 8,780 & 74038 & 74038 \\
Observations & 74038 & 74038 & & \\
\hline \hline
\end{tabular}

Notes: ${ }^{*} p<0.1,{ }^{* *} p<0.05,{ }^{* * *} p<0.01$, with standard errors clustered at the country*4-digit SIC level. These are negative binomial regressions on data at the firm-year level from 1996 to 2005. The dependent variable is patents plus one in column (1) (BDvR's specification) and simply patents in columns (2)-(4). Column (1) is an exact replication of BDvR Table 7, Column (3). Column (4) is the regression BDvR intended to run.

\section{Conclusion}

BDvR find that Chinese competition may have caused a dramatic 30\% increase in patent growth in Europe over the period 1996-2005. Yet, we uncover several coding errors in an important robustness check that, when fixed, render their results insignificant, or even suggest a negative correlation between Chinese competition and patents. We show that the decline in patents (in their data) was similar for both China-competing and noncompeting sectors. We find that BDvR's results are an artifact of their "patents plus one" normalization, the relatively low level of patents in China-competing sectors, and the tapering of the patent data. We conclude that the oft-cited finding that Chinese competition increased innovation in Europe is not robust. More research focused on making methodological improvements and extending the patent data series would be helpful. 


\section{References}

Autor, D., D. Dorn, G. H. Hanson, G. Pisano, and P. Shu. Forthcoming. Foreign Competition and Domestic Innovation: Evidence from US Patents. Technical report. AEJ: Insights.

Bellego, C., and L.-D. Pape. 2019. Dealing with the Log of Zero in Regression Models. Working Papers 2019-13. Center for Research in Economics and Statistics, August.

Bellemare, M. F., and C. J. Wichman. 2020. "Elasticities and the Inverse Hyperbolic Sine Transformation." Oxford Bulletin of Economics and Statistics 82 (1): 50-61.

Bloom, N., M. Draca, and J. Van Reenen. 2016. "Trade Induced Technical Change? The Impact of Chinese Imports on Innovation, IT and Productivity." The Review of Economic Studies 83 (1): 87-117.

Hausman, J., B. H. Hall, Z. Griliches, et al. 1984. "Econometric Models for Count Data with an Application to the Patents-R\&D Relationship." Econometrica 52 (4): 909938.

Head, K., and T. Mayer. 2014. "Gravity Equations: Workhorse, Toolkit, and Cookbook." In Handbook of International Economics, 4:131-195. Elsevier.

Pierce, J. R., and P. K. Schott. 2012. "Concording US Harmonized System Codes over Time." Journal of Official Statistics 28 (1): 53-68.

Silva, J. S., and S. Tenreyro. 2006. "The Log of Gravity." The Review of Economics and statistics 88 (4): 641-658. 